ホルムアルデヒドの食品への吸着と調理後の残存

石田 裕* · 舟木 秀明** · 鈴野 弘子*

(*東京農業大学短期大学部, **服部栄養専門学校)

\title{
The adsorption of formaldehyde to foods and the residue after cooking
}

\author{
Hiroshi Ishida*, Hideaki Funaki**, Hiroko Suzuno* \\ *Tokyo University of Agriculture Junior College, 1-1-1 Sakuragaoka Setagaya-ku, Tokyo, 156-8502 \\ **Hattori Nutrition College, 5-25-4 Sendagaya Sibuya-ku, Tokyo, 151-0051 \\ *テ156-8502 東京都世田谷区桜丘 1-1-1 \\ **⿳151-0051 東京都渋谷区千駄ヶ谷 5-25-40
}

\begin{abstract}
Recently, sick house syndrome caused by formaldehyde has been gaining attention in Japan. Formaldehyde is toxic substance and its main intake is considered through the airways, but if formaldehyde is rapidly adsorbed to foods, the intake by eating is also possible. Therefore, evaluation of the transfer of formaldehyde to food is important for the public hygiene. When casein, starch, and soybean oil were exposed to formaldehyde, the amount of adsorbed formaldehyde was the largest in casein, followed by starch, while it was very small in soybean oil. The adsorption of formaldehyde to casein and starch was increased till 96 hours without reaching the maximum, and suggesting that their adsorption can continue in long-term storage. The concentration of formaldehyde in the atmosphere was increased with the rise of temperature, and the amount of adsorbed formaldehyde was correlated with the rise of temperature. The adsorption of formaldehyde was less in the wrapped samples than in the unwrapped samples. Polypropylene-wrapping provided higher protection against formaldehyde than polyethylene-wrapping. About $80 \%$ formaldehyde was removed by boiling, but almost all formaldehyde remained in the samples such as powdered milk that are dissolved.
\end{abstract}

\section{緒 言}

近年，収納家具や家屋の壁，集合材などの接着等に防 腐, 抗菌の目的で用いられるホルムアルデヒド（以下 「HCHO」という。）による，シックハウス症候群が問 題視されている1),2)。

$\mathrm{HCHO}$ が含まれる接着剤等を使用した戸棚や家具， 建材などが通気の悪い状況におかれれば人間ばかりでな く食品も常に一定濃度の HCHO に曝されることになる。 特に夏場などの気温が高いときには環境中 HCHO 濃度 の上昇と共に食品への移行量も増加することが予測され る。 HCHO は常温で無色透明の気体または液体で，急 性毒性があり，発ガン性も疑われている3) 5)。また経口 毒性も示されて抢り6), 日本産業衛生学会で定められた
大気中の許容濃度は $0.5 \mathrm{ppm}$, 厚生労働省の指針值では $0.8 \mathrm{ppm}$ (約 $0.1 \mathrm{mg} / \mathrm{m}^{3}$ に相当), 水道水の水質基準では $0.08 \mathrm{mg} / \mathrm{L}$ 以下が定められている。また HCHO は防腐 効果が高いため, 過去には違反事例として食品への添加 もみられた ${ }^{7)}$ 。さらに最近では数 $\mathrm{mg} / \mathrm{kg}$ と微量である が養殖フグにおける HCHO の残留（2003年）が社会問 題となった。

シックハウス症候群における $\mathrm{HCHO}$ の体内取り込み は主に気道経路が考えられるが, 食品への吸着が容易に 起これば，契食による取り込みも経路として考えられる。 これらのことから, 食品の保存時における, HCHOの 食品への移行状況を明らかにすることは食生活における 安全性を考えるうえでも意義がある。

そこで食品成分として，炭水化物を主成分とするデン 
プン ${ }^{8)}$ ，タンパク質を主成分とするカゼイン ${ }^{8)}$ ，脂質を 主成分とする大豆油8) を用いて，それらの食品成分と $\mathrm{HCHO}$ 曝露時の吸着量との相関について検討を行った。 さらに実際に保存性のある食品への吸着, 調理加工によ る消長ならびに食品への移行阻止を目的として包装材に よる $\mathrm{HCHO}$ 透過防止効果についても検討したので報告 する。

\section{実験方法}

\section{1. 吸着試験用試料およびその調製}

食品に対応する食品対照標準試料（以下「対照試料」 という。）としてカゼイン（乳製）およびデンプン（ば れいしょ）は試薬 1 級関東化学(侏製, ダイズ油は局法 （小堺製薬(株)製）を用いた。

また吸着および調理による消長に関する試験には，一 般に市販されている食品で開封後もある程度の期間の保 存が予測されるものとして, 粉ミルク（缶入り乳児用粉 ミルク， M社製)，乾湎（乾しうどん， $3.5 \mathrm{~mm} \times 1.8 \mathrm{~mm}$, $\mathrm{N}$ 社製)，スパゲッティ（乾燥スパゲッティ，直径 1.6 $\mathrm{mm}, \mathrm{M}$ 社製), 米 (精白米コシヒカリ, 新潟県産) な どの市販食品（以下「市販食品試料」という。）を用い た。なお本実験で用いた市販食品試料の一般成分分析值 は Table 1 のとおりである。

\section{2. 試薬およびその調製}

$\mathrm{HCHO}$; ホルマリン試薬, 濃度 $35 \%$ 以上は試薬特級, 和光純薬工業(陎)製を用いた。

比色定量用 HCHO 標準溶液抢よび飽和用 $\mathrm{HCHO}$ 溶 液（1.0\%，0.10\%，0.01\%）; 両者の HCHO 溶液はホ ルマリン試薬から $1.0 \mathrm{~g} / 100 \mathrm{~m} l$ の HCHO 溶液を作成し, アセチルアセトン法 ${ }^{9}$ 標準溶液調製の項に従い正確な $\mathrm{HCHO}$ の濃度を求めた。次いで必要な濃度に希釈し $\mathrm{HCHO}$ 標準溶液およびデシケータ内に静置する飽和用 $\mathrm{HCHO}$ 溶液とした。

HPLC 用標準液および GC-MS 用標準液はホルムア ルデヒド- 2,4 ジニトロフェニルヒドラゾン（以下 $「 \mathrm{HCHO}-\mathrm{DNPH} 」$ とう。）排ガス分析用標準試薬 （HCHO として $300 \mu \mathrm{g} / \mathrm{m} l$ 溶液，和光純薬工業(侏)製）を
適宜メタノールで希釈し調製した。

誘導体化用 2,4 ジニトロフェニルヒドラジン試薬は 試薬特級（関東化学(侏)製）を用い， $2 \mathrm{M}$ 塩酸溶液に $2 \%$ の割合で溶解後ろ過し DNPH 塩酸溶液として調製した。 クリンアップカートリッジは GL-Pak PLS- 2 （ジー エルサイエンス(侏)製）にメタノール $50 \mathrm{~m} l$, 純水 $20 \mathrm{~m} l$ を 通過させた後用いた。

有機溶媒および一般的な試薬はいずれも試薬特級, 関 東化学(侏製を用いた。

\section{3．装置および測定条件}

分光光度計は UV-1200（侏島津製作所製）を用いた。 気相中 HCHO 濃度の測定は既報 ${ }^{10)}$ に準じて DNPH 化後, 高速液体クロマトグラフィーの HPLC ポンプは DS- 4 (Shodex 製), 検出器は L-4200（日立製作所(侏) 製), 恒温器は CTO-10AS (侏島津製作所製), オート サンプラーは SIL-10AD（侏島津製作所製）を用いた。

測定条件はカラム Mightysil-RP18, $15 \mathrm{~cm} \times 4 \mathrm{mmI}$.D. 関東化学(侏)製, 温度 $40{ }^{\circ} \mathrm{C}$, 溶離液アセトニトリル : 水 $=$ $45: 55$, 流量 $0.8 \mathrm{ml} / \mathrm{min}$., 測定波長 $355 \mathrm{~nm}$ とした。

さらに市販食品試料に吸着した HCHO の確認には GC-MS QP2000 EI（侏島津製作所製）を用いた。測定 条件はカラム DB- 5 膜厚 $0.25 \mu \mathrm{m}, 30 \mathrm{~m} \times 0.25 \mathrm{mmI}$.D. ( $\mathrm{J} \& \mathrm{~W}$ 製), カラム温度 $120^{\circ} \mathrm{C}$ で5分間維持後, $5{ }^{\circ} \mathrm{C} /$ min. で $280{ }^{\circ} \mathrm{C}$ まで昇温, 注入口温度は $280^{\circ} \mathrm{C}$, セパレー ター温度は $300^{\circ} \mathrm{C}$, イオン源温度は $300^{\circ} \mathrm{C}$, エレクトロン エネルギーは $70 \mathrm{eV}$, キャリアーガスは純ヘリウム $0.5 \mathrm{~kg}$ $/ \mathrm{cm}^{2}$ とした。

フィルムの材質確認には赤外分光光度計 A202（日本 分光(侏製)を用いた。

\section{4. 試験法}

1) 対照試料と市販食品試料に対する $\mathrm{HCHO}$ 曝露濃 度の検定および暴露条件の設定

(1) 気相中 HCHO 濃度の経時変化の測定

予備実験として，デシケーター中の HCHO 飽和蒸気 圧に関する検討を行った。 $10.0 \mathrm{mg} / \mathrm{ml}(1.0 \%), 1.0 \mathrm{mg}$ $/ \mathrm{m} l(0.10 \%), 0.10 \mathrm{mg} / \mathrm{m} l(0.01 \%)$ に調製した各

Table 1 Compositions in four kinds of foods (gram per $100 \mathrm{~g}$ ) a

\begin{tabular}{lcccc}
\hline & Powdered milk & Hoshi-udon (Raw) & Spaghetti (Raw) & Well-milled rice (Raw) \\
\hline Moisture & $2.7 \pm 0.05$ & $10.4 \pm 0.01$ & $10.6 \pm 0.01$ & $15.2 \pm 0.05$ \\
Protein & $15.6 \pm 0.01^{\mathrm{b}}$ & $9.4 \pm 0.02^{\mathrm{c}}$ & $13.8 \pm 0.01^{\mathrm{c}}$ & $4.9 \pm 0.01^{\mathrm{d}}$ \\
Lipid & $16.4 \pm 0.08$ & $2.5 \pm 0.03$ & $2.8 \pm 0.37$ & $1.6 \pm 0.08$ \\
Ash & $4.1 \pm 0.07$ & $3.8 \pm 0.01$ & $0.8 \pm 0.01$ & $0.6 \pm 0.07$ \\
Carbo-hydrate & $61.0 \pm 0.43$ & $73.9 \pm 0.05$ & $71.8 \pm 0.37$ & $77.8 \pm 0.10$ \\
\hline
\end{tabular}

a : Values are means of triplicate determinations

b : Total nitrogen $\times 6.38$ gram per $100 \mathrm{~g}$

c : Total nitrogen $\times 5.70$ gram per $100 \mathrm{~g}$

$\mathrm{d}:$ Total nitrogen $\times 5.94$ gram per $100 \mathrm{~g}$

e : Calculated by the following equation : 100 - (moisture + protein + lipid + ash $)$ 
$\mathrm{HCHO}$ 溶液 $10 \mathrm{~m} l$ を直径 $9 \mathrm{~cm}$ のガラスシャーレ（以下 「シャーレ」という）に入れ，それをあらかじめ $20{ }^{\circ} \mathrm{C} と$ $30{ }^{\circ} \mathrm{C}$ に保温した 5 L容のデシケーター内に静置後密閉し, $20^{\circ} \mathrm{C}$ または $30^{\circ} \mathrm{C}$ の恒温器内に放置した。次いで経時的に, シリコンゴムセプタムを介して $25 \mathrm{~m} l$ プラスチックシリ ンジにデシケーター内の気相 $20 \mathrm{~m} l$ を採り, $\mathrm{DNPH}$ 塩酸 溶液 $4 \mathrm{~m} l$ と濃塩酸 $1 \mathrm{~m} l$ を加え 5 分間激しく振とうし, 気相中 HCHO の DNPH 化を行った。さらにこの溶液 をクリンアップカートリッジでクリンアップし，メタ ノールで溶出後 HPLC 法により気相中 HCHO 濃度を測 定した10) 12)。

\section{(2) 吸着試験用試料の調製}

3 種の対照試料を各々 $2.0 \mathrm{~g}$ ずつ，直径 $5 \mathrm{~cm}$ のシャー レに均等に広げて入れこれを各濃度に調製した $\mathrm{HCHO}$ 溶液 $(10.0 \mathrm{mg} / \mathrm{m} l, 1.0 \mathrm{mg} / \mathrm{m} l, 0.10 \mathrm{mg} / \mathrm{m} l) 10 \mathrm{~m} l$ ず つを入れたシャーレと共に，あらかじめ $20^{\circ} \mathrm{C}$ あいは 30 ${ }^{\circ} \mathrm{C}$ に保温したデシケーター中に Fig.1 に示すように静置 し，24，48，96時間後に取り出し吸着試験用対照試料と した。

また市販食品試料（粉ミルク，乾麺，スパゲッティ， 米）は粉挽処理後ふるいでメッシュ500 $\mu \mathrm{m}$ 通過 $125 \mu \mathrm{m}$ 不通過分を各 $2.0 \mathrm{~g}$ ずつシャーレに入れ，同一条件でデ シケーター中に静置し，24，48，96時間後に取り出し吸 着試験用市販食品試料とした。なお吸着試験用の各試料 については，あらかじめ HCHO が検出されないことを 確認した。

(3) 吸着試験後の対照試料および市販食品試料中 $\mathrm{HCHO}$ の定量

吸着試験後の各試料を $150 \mathrm{~m} l$ 容の水蒸気蒸留用 2 口フ ラスコに移し，水 $20 \mathrm{~m} l$ および $20 \%$ リン酸 $1 \mathrm{~m} l$ を加えた 後, 水 $20 \mathrm{~m} l$ を入れたメスシリンダーを受器として, 冷 却器のガラス管の先が浸るようにして蒸留液が約 $180 \mathrm{~m} l$ になるまで水蒸気蒸留を行った ${ }^{13)}$ 。次いで水を加え $200 \mathrm{~m} l$ に定容後混和し蒸留試験溶液として，アセチルア セトン法9)による測定に供した。なお定量範囲を超える ものについては適宜水で希釈し測定した。

（4） GC-MS による吸着試験後の市販食品試料中 $\mathrm{HCHO}$ の確認

蒸留試験溶液について，既報10),11) に従いDNPH で 誘導体化後，小出らの方法 ${ }^{12)}$ 準じてクリンアップカー

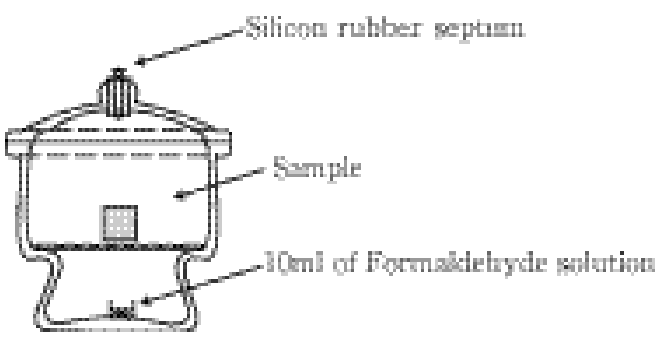

Fig. 1 Formaldehyde adsorbing method for samples (capacity of desiccators were $5 \mathrm{~L}$ )
トリッジに負荷し，純水 $20 \mathrm{~m} l$ で洗浄，メタノール $10 \mathrm{~m} l$ で溶出してクリンアップし，HCHO-DNPH 標準液を対 照として GC-MSで確認を行った。

2 ) 調理によるホルムアルデヒドの除去に関する試験

(1) 調理試料の調製

調理による HCHO の除去率を明確にするために，気 相中濃度は実態より高い濃度条件で行った。各温度に保 温したデシケーター中に $1.0 \% \mathrm{HCHO}$ 溶液を $10 \mathrm{~m} l$ と, 市販食品試料（粉ミルク，乾湎，スパゲッティ）をその ままの形態で各 $12.0 \mathrm{~g}$ ずつ，また米は $22.0 \mathrm{~g}$ を入れ， 20 ${ }^{\circ} \mathrm{C} 48$ 時間静置した。次いで HCHO 吸着試験後の粉ミル クの重量を測定し, 吸着試験前重量に換算して $10.0 \mathrm{~g}$ 相 当量を哺乳瓶に移し入れ, $50{ }^{\circ} \mathrm{C}$ の温水を内容物総重量で $75 \mathrm{~g}$ まで加え振とう溶解し調理試料とした。

また吸着試験後の乾湎およびスパゲッティについても 同様に吸着試験前の $10.0 \mathrm{~g}$ 相当量を採り，沸騰水 $100 \mathrm{~g}$ 中に投入し，かき混ぜながら10分間ゆでた。次いで湯切 りし，室温で10分間放置したものを調理試料とした。 米も同様に吸着試験前の $20.0 \mathrm{~g}$ 相当量を 5 倍量の水で 3 回洗浄し水切り後, 再度水を加え全重量が 2.5 倍量に なるように調整し炊飯（東芝 RCK- 5 JT-0.54 L ），炊 きあがり後30分間炊飯器内に保温したものを炊飯調理試 料とした。なお調理後の出来上がり量は 3 回の繰り返し で, 吸着溶解粉ミルク $75 \pm 0.0 \mathrm{~g}$, 吸着茹で乾湎 $28.8 \pm$ $0.6 \mathrm{~g}$, 吸着茹でスパゲッティ $24.8 \pm 0.2 \mathrm{~g}$, 吸着炊飯米 は $46.2 \pm 2.8 \mathrm{~g}$ であった。

(2) 調理前後の HCHO の測定

同時に吸着試験後の市販食品試料（吸着試験前の市販 食品試料の重量換算で $2.0 \mathrm{~g}$ 相当量） と, 調理後の市販 食品試料 (吸着試験前の市販食品試料換算で $5 \mathrm{~g}$ 相当量) を秤取し, 水蒸気蒸留法で HCHO を分取し, アセチル アセトン法で定量, 調理後の残存率を求めた。

\section{3 ）包装内の食品の吸着量測定による $\mathrm{HCHO}$ のフィ} ルム透過性試験

(1) 測定用試料の調製

一般的に食品の容器包装用によく用いられるプラスチ ック包装材としてポリエチレン $(\mathrm{PE})$ とポリプロピレ ン $(\mathrm{PP})$ があげられる。そこで本実験で PE は厚さ0.03 $\mathrm{mm}$ の低密度 $\mathrm{PE}$ (矢崎加工(侏製)，PP は厚さ $0.03 \mathrm{~mm}$ のフィルム（侏シモジマ製）を用い $10 \mathrm{~cm} \times 10 \mathrm{~cm}$ の袋を 作成した。次いでこの中に大豆油を除く対照試料 $2.0 \mathrm{~g}$ ずつを封入し，水中に沈めピンホールのないことを確認 後, $1.0 \%$ および $0.10 \%$ のCHO $10 \mathrm{ml}$ を入れたデシケー ター内に入れ， $20^{\circ} \mathrm{C} 96$ 時間放置し包装吸着試料とした。 また複層フィルムであるスパゲッティの包装についても 同様に透過性試験を行った。

（2）フィルムを透過した HCHO の測定

包装吸着試料を取り出しアセチルアセトン法で吸着量 測定を行った。な扮使用した包装材は赤外分光光度計を 用いて材質を確認した。 


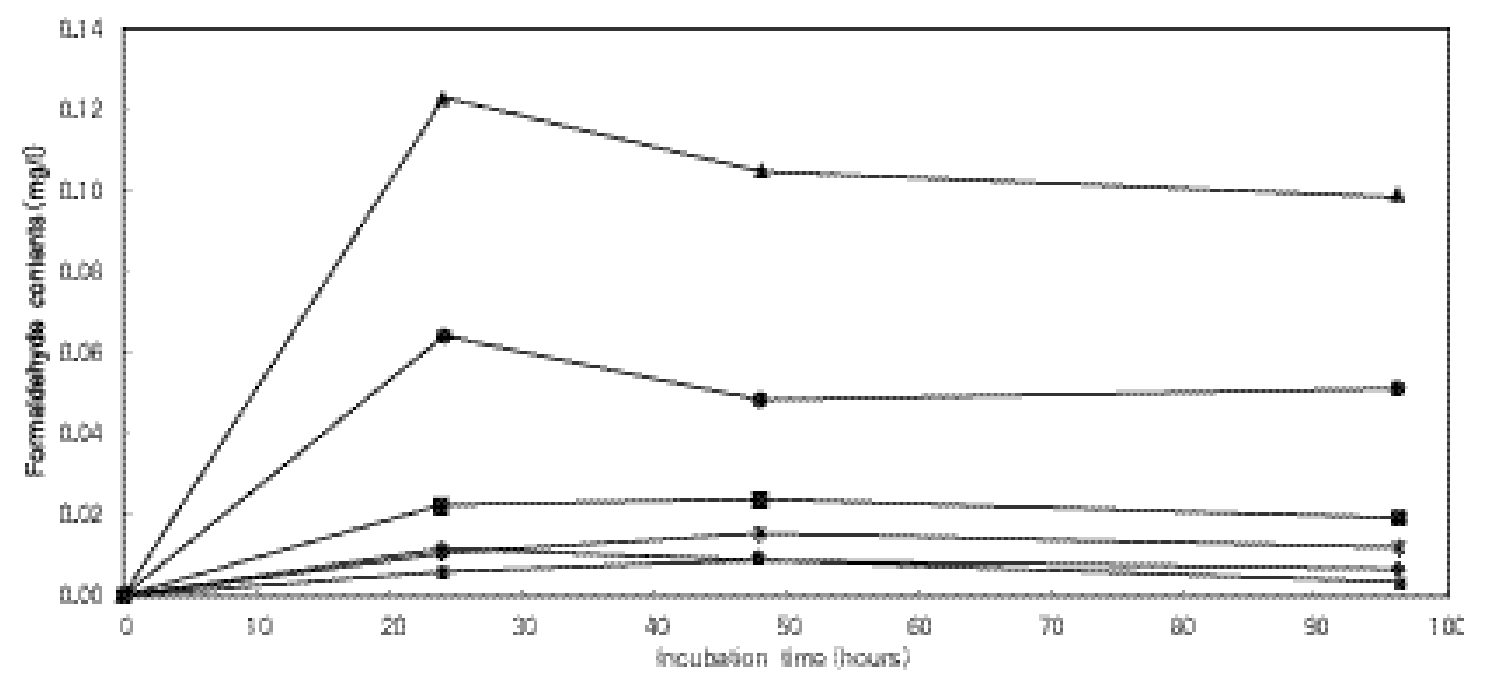

Fig. 2 Time cause of formaldehyde contents in gaseous phase

- stand at $30^{\circ} \mathrm{C}$ with $0.01 \%$ of $\mathrm{HCHO}$ sol.

$\boldsymbol{\Delta}$ stand at $30^{\circ} \mathrm{C}$ with $1.0 \%$ of $\mathrm{HCHO}$ sol.

* stand at $20{ }^{\circ} \mathrm{C}$ with $0.1 \%$ of $\mathrm{HCHO}$ sol.

\section{結果及び考察}

1. デシケーター内, 気相中ホルムアルデヒド濃度の $20^{\circ} \mathrm{C}, 30^{\circ} \mathrm{C}$ における経時的変化

シャーレに $1.0 \%, 0.10 \%, 0.01 \%$ の HCHO 水溶液 $10 \mathrm{ml}$ を入れたデシケーター内気相中の HCHO 濃度を経 時的に測定した結果を Fig.2 に示した。1.0\% HCHO 溶 液 $10 \mathrm{~m}$ を入れた $5 \mathrm{~L}$ 容デシケーターを $20{ }^{\circ} \mathrm{C} て ゙$ 放置した 時の気相濃度は，24〜96時間では0.06〜0.05mg/L，30 ${ }^{\circ} \mathrm{C}$ では $0.12 \sim 0.10 \mathrm{mg} / \mathrm{L}$ で推移した。また $0.10 \%$ 溶液を 用いた場合， $20{ }^{\circ} \mathrm{C}$ では $0.010 \sim 0.012 \mathrm{mg} / \mathrm{L}, 30^{\circ} \mathrm{C}$ では $0.022 \sim 0.019 \mathrm{mg} / \mathrm{L}$ で， $0.010 \% \mathrm{HCHO}$ 溶液を用いた場 合は $20{ }^{\circ} \mathrm{C}$ で0.006〜 $0.005 \mathrm{mg} / \mathrm{L}, 30^{\circ} \mathrm{C}$ では $0.010 \sim 0.006$ $\mathrm{mg} / \mathrm{L}$ であった。

この結果から気相中 HCHO 濃度は24時間から96時間 の範囲で大きな変動は認められなかった。またデシケー

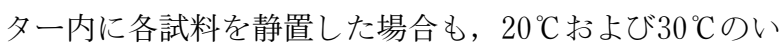
ずれの放置条件においても気相中の $\mathrm{HCHO}$ 濃度に明ら かな差は認められなかった。これは密閉された容器内で は同一条件で放置された場合，同一組成の溶液の飽和蒸 気圧は一定となる14)ことに一致した。また放置温度の違 いで気相中の HCHO 飽和蒸気圧は異なり, 密閉された 条件であれば $\mathrm{HCHO}$ の濃度は $20{ }^{\circ} \mathrm{C}$ と $30{ }^{\circ} \mathrm{C}$ で2倍程度の 差が示された。

\section{2. 対照試料のホルムアルデヒド吸着量}

Fig.3 に示すと打り，カゼイン抢よびデンプンは $20^{\circ} \mathrm{C}$, $30{ }^{\circ} \mathrm{C}$ のいすれれの条件においても放置時間の延長に伴い吸 着量は増加した。また放置温度による吸着量の比較では, 高温で明らかに吸着量の増加が認められた。しかし大豆 油は HCHO をほとんど吸着せず，経時的な増加も見ら れなかった。
- stand at $30^{\circ} \mathrm{C}$ with $0.1 \%$ of $\mathrm{HCHO}$ sol.

- stand at $20{ }^{\circ} \mathrm{C}$ with $0.01 \%$ of $\mathrm{HCHO}$ sol.

- stand at $20^{\circ} \mathrm{C}$ with $1.0 \%$ of HCHO sol.
この違いについては HCHO が極性物質で親水性を有 し，分子内にアミノ基やカルボキシル基をもつカゼイン， アルコール基を有するデンプンも親水性物質であり, 同 様の性質を持つ物質として吸着量が高まること, 逆に疎 水性の高い油脂は，親水性の高い $\mathrm{HCHO}$ とは親和性が 低いことが原因として考えられた ${ }^{15)} 。$

またカゼインとデンプンは吸湿性がありデシケーター 内気相中の水分を吸着するが，大豆油は水分をほとんど 含まないことや, 形態の違いによる表面積の違いも吸着 量が異なる一つの要因と考えられた。

以上のことからカゼインおよびデンプンは被曝濃度が 高まるにつれて吸着量も高まり，放置時間の延長によっ て吸着量はさらに上昇することが示唆された。

\section{3. タンパク質および糖質を主成分とする保存食品の ホルムアルデヒド吸着能}

4 種の市販食品試料を粉砕処理後 $0.10 \% \mathrm{HCHO} 10 \mathrm{~m} l$ を入れたデシケーター $(\mathrm{HCHO}$ 気相濃度約 $0.01 \mathrm{mg} / \mathrm{L})$ 中, $20{ }^{\circ} \mathrm{C}$ で被曝させた。その結果, Fig.4 に示すとおり タンパク質と糖質含有量の高い保存食品として乳児用粉 ミルクを用いた時， 24 時間で $0.12 \mathrm{mg} / \mathrm{g} ， 48$ 時間で 0.28 $\mathrm{mg} / \mathrm{g}, 96$ 時間で $0.53 \mathrm{mg} / \mathrm{g}$ の吸着がみられた。

糖質を主成分とする食品として乾湎を用いた時は，24 時間で $0.10 \mathrm{mg} / \mathrm{g}, 48$ 時間で $0.20 \mathrm{mg} / \mathrm{g}$, 96時間で $0.49 \mathrm{mg} / \mathrm{g}$ の吸着がみられた。またスパゲッティを用い たときは24時間で $0.07 \mathrm{mg} / \mathrm{g}, 48$ 時間で $0.18 \mathrm{mg} / \mathrm{g}$, 96時 間で $0.42 \mathrm{mg} / \mathrm{g}$ の吸着が見られ，米では 24 時間で 0.09 $\mathrm{mg} / \mathrm{g}, 48$ 時間で $0.19 \mathrm{mg} / \mathrm{g}, 96$ 時間で $0.39 \mathrm{mg} / \mathrm{g}$ の吸着 がみられた。

さらに $30^{\circ} \mathrm{C} ， 0.10 \% \mathrm{HCHO} 10 \mathrm{~m} l$ を入れたデシケー ター（気相濃度約 $0.02 \mathrm{mg} / \mathrm{L} ）$ 中で被曝させた場合, 粉 ミルクは24時間で $0.16 \mathrm{mg} / \mathrm{g}, 48$ 時間で $0.28 \mathrm{mg} / \mathrm{g}$, 96時 


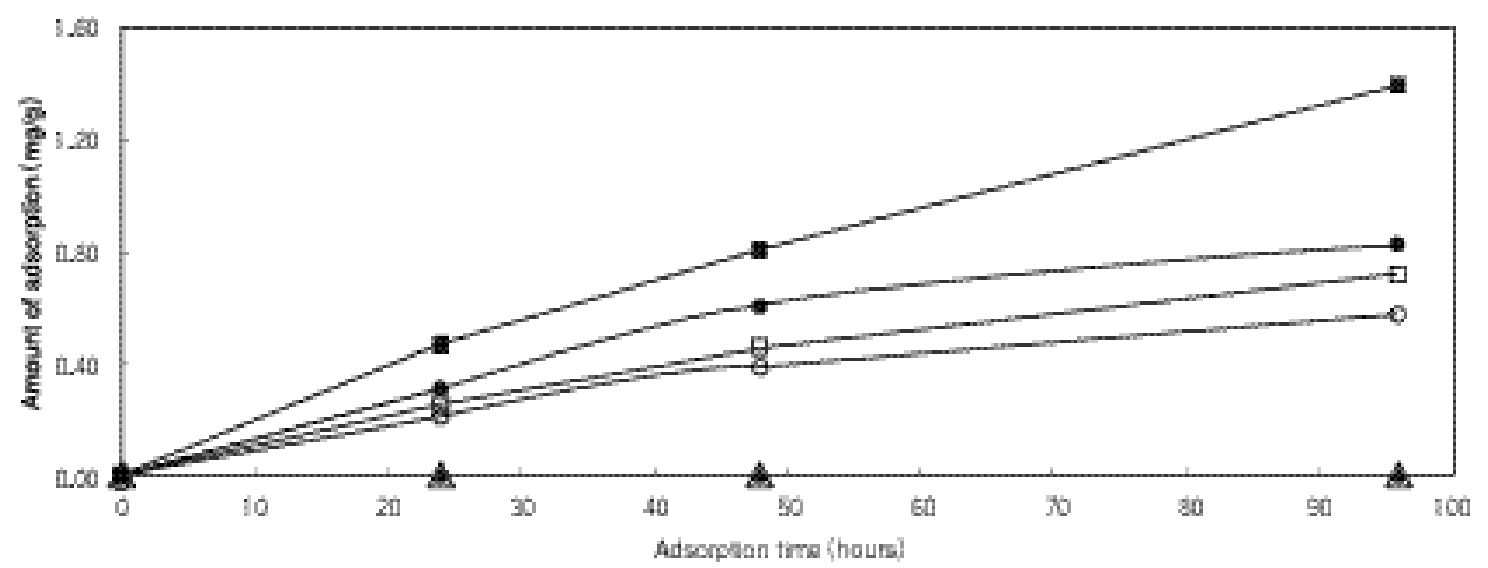

Fig.3 Adsorption rates of formaldehyde for casein, starch and soybean oil

Experimental conditions : Samples were placed in desiccators with $10 \mathrm{ml}$ of $0.10 \% \mathrm{HCHO}$ solution and analyzed after 24, 48 and 96 hours. ( $\mathrm{HCHO}$ contents in gaseous phases were about $0.01 \mathrm{mg} / \mathrm{L}$ at $20^{\circ} \mathrm{C}$ and $0.02 \mathrm{mg} / \mathrm{L}$ at $30^{\circ} \mathrm{C}$ )
$\square \quad 2 \mathrm{~g}$ of casein placed at $20^{\circ} \mathrm{C}$
$-2 \mathrm{~g}$ of starch placed at $20^{\circ} \mathrm{C}$
$\triangle 2 \mathrm{~g}$ soybean oil placed at $20^{\circ} \mathrm{C}$
- $2 \mathrm{~g}$ of casein placed at $20^{\circ} \mathrm{C}$
- $2 \mathrm{~g}$ of starch placed at $30^{\circ} \mathrm{C}$
- $2 \mathrm{~g}$ of soybean oil placed at $30^{\circ} \mathrm{C}$
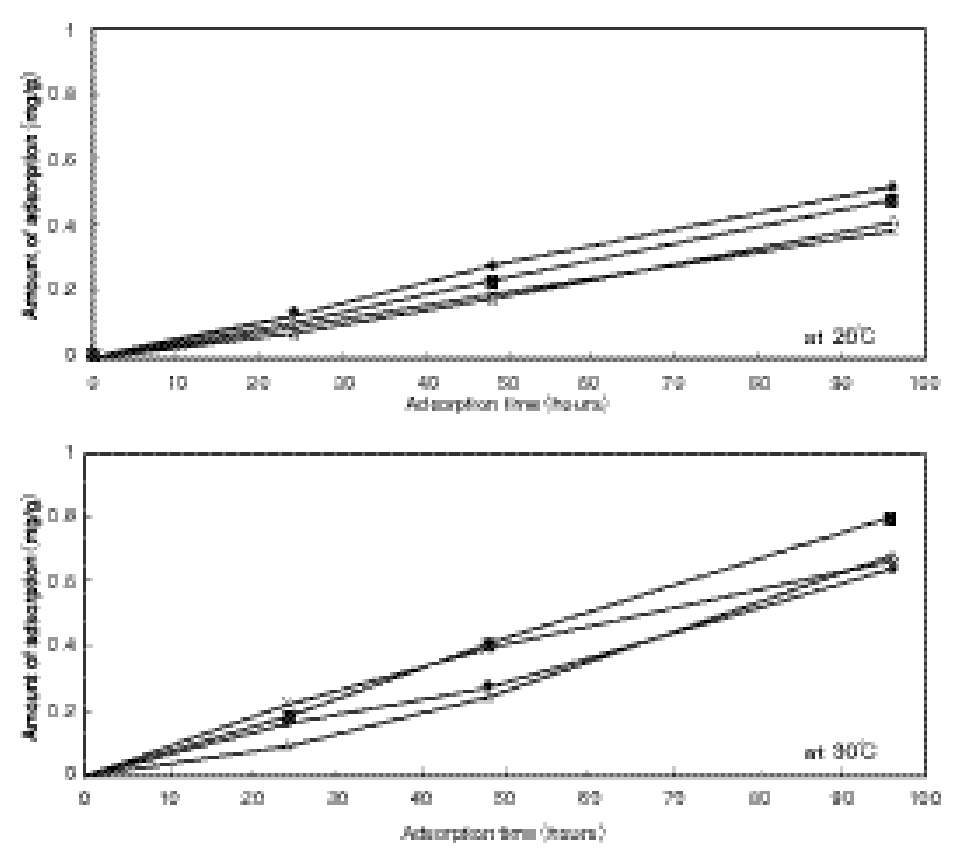

Fig.4 Adsorption rates of formaldehyde for commercialized foods Experimental conditions : Tow grams of samples were placed in desiccators with $10 \mathrm{ml}$ of $0.10 \% \mathrm{HCHO}$ solution and analyzed after 24,48 and 96 hours. ( $\mathrm{HCHO}$ contents in gaseous phases were about $0.01 \mathrm{mg} / \mathrm{L}$ at $20^{\circ} \mathrm{C}$ and 0.02 $\mathrm{mg} / \mathrm{L}$ at $\left.30^{\circ} \mathrm{C}\right)$

Powdered milk

Hoshi-udon (raw) $\triangle$ Spaghetti (raw)

$\times$ Well milled rice (raw)

間で $0.66 \mathrm{mg} / \mathrm{g}$ の吸着がみられ，乾湎は 24 時間で 0.18 $\mathrm{mg} / \mathrm{g} ， 48$ 時間で $0.41 \mathrm{mg} / \mathrm{g} ， 96$ 時間で $0.81 \mathrm{mg} / \mathrm{g}$ の吸 着がみられた。またスパゲッティでは24時間で $0.09 \mathrm{mg} /$ $\mathrm{g}, 48$ 時間で $0.25 \mathrm{mg} / \mathrm{g}, 96$ 時間で $0.69 \mathrm{mg} / \mathrm{g}$ の吸着がみ られ，米では24時間で $0.22 \mathrm{mg} / \mathrm{g}, 48$ 時間で $0.40 \mathrm{mg} / \mathrm{g}$, 96 時間で $0.68 \mathrm{mg} / \mathrm{g}$ の吸着がみられた。
この傾向は対照試料に対応した值であり, 一般的な保存食品もタンパク質および糖質を 主成分とする食品は十分 HCHO 吸着物質に なりうることが示された。

また粉ミルクと乾湎を用いての吸着実験後 試料の水蒸気蒸留留液について DNPH で誘 導体化後 GC-MSにより確認を行いその結 果を Fig.5 に示した。標準 HCHO-DNPH と 同じ保持時間にピークが検出され，分子イオ

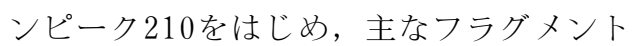
(180，152，122，91，79など）が一致するマ ススペクトルが得られた。このことから吸着 物質はホルムアルデヒドと同定され, 新築住 宅や食器戸棚などの環境中から HCHO の食 品への移行の可能性が示された。

\section{4. ホルムアルデヒドの調理による消長}

4 種の HCHO 吸着試験後の市販食品試料 を実験方法 4 の 2 ）-(1)項の調理法に従い調 理後, 残存量を測定し Fig.6に示した。吸着 試験前の重量に換算して比較した結果，3回 のくりかえしで粉ミルクについては83.1 4 . 0 $\%$, 乾湎では $23.8 \pm 1.8 \%$, スパゲッティで は $17.7 \pm 0.93 \%$ ，米では $55.2 \pm 1.6 \%$ の残存 がみられた。調理法について比較すると乾麺 やスパゲッティなどゆでた後, ゆで水を除去 するものについては摂取する部分への残留は $30 \%$ 以下に なり，吸着した HCHO はかなり除去されるが，溶解の み，あるいはゆで水を含めて摂取するような調理法では 除去率が低かった。これらの結果は乾物の調理法とし ては多量の湯を用いて，ゆでこぼすことが吸着した HCHO の除去に有効であることを示している。 

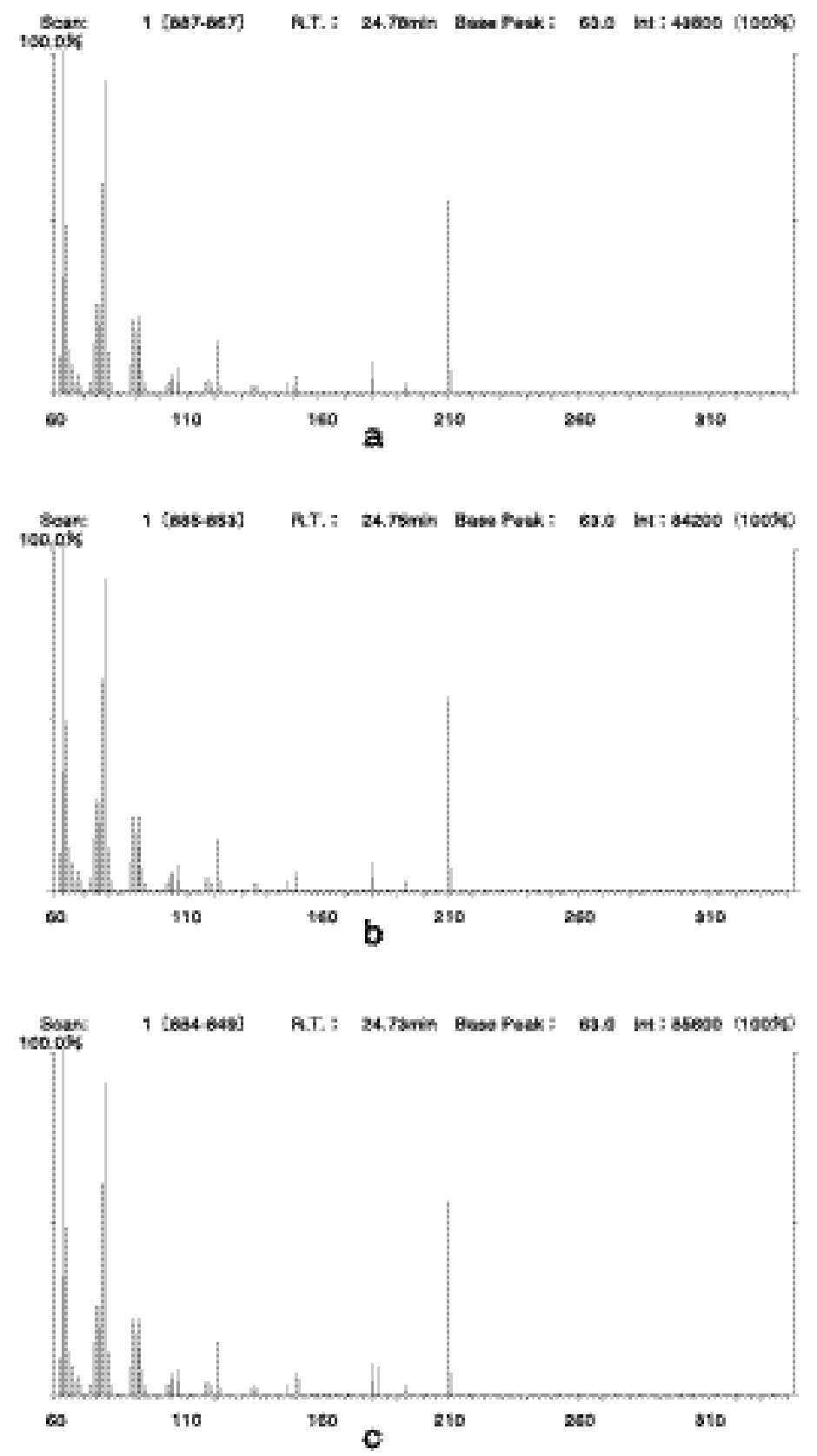

Fig.5 Mass spectra of formaldehyde2, 4-dinitrophenylhydrazone a. Standard b. Sample (hoshi-udonraw) c. Sample (powdered milk)

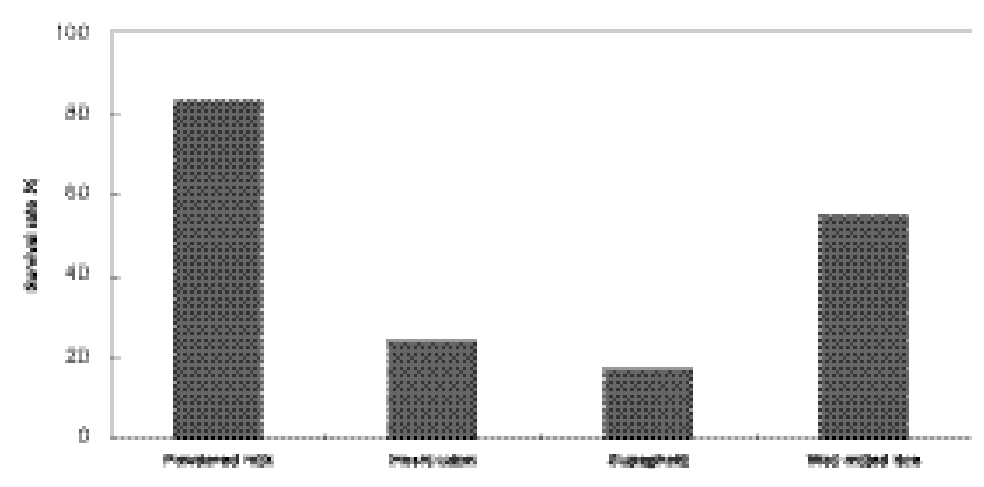

Fig.6 Survival rates of formaldehyde after cooking
5. ホルムアルデヒドの包装フィルム透過性 試験

吸着した食品中の HCHO は煮炊きする調理 法では多くが残存し，除去することが困難であ った。そこでHCHO の吸着を防ぐことを目的 として $\mathrm{PE}$ 抢よ゙ $\mathrm{PP}$ 包装の有効性について検 討した。透過性の確認は包装フィルム内食品中 への HCHO 吸着量測定により行った。使用し た包装材の材質については赤外分光光度計で確 認した結果, 既報 ${ }^{16)}$ と同様の赤外吸収特性が得 られ PEとPPであることが確認された。

次いで PEとPPの袋の中に対照試料 $2.0 \mathrm{~g}$ ずつを封入し， $1.0 \% \mathrm{HCHO} 10 \mathrm{~m} l$ を入れたデ シケーター内で, $20^{\circ} \mathrm{C}, 96$ 時間の暴露実験を行 った。その結果, PE 包装したカゼインは無包 装 $(2.73 \mathrm{mg} / \mathrm{g})$ に対して7.3\% (0.199mg/g)， デンプンは無包装 $(1.93 \mathrm{mg} / \mathrm{g})$ に対して 11.4 \% (0.220mg/g) の吸着しかみられなかった。 さらに PP 包装では同条件の暴露において, カ ゼインは無包装に対して $1.5 \%(0.04 \mathrm{mg} / \mathrm{g})$, デンプンは $1.6 \%(0.03 \mathrm{mg} / \mathrm{g})$ の吸着しか見ら れず，包装材により $\mathrm{HCHO}$ 透過量の差はある ものの，透過の阻止は明らかであった。

同様に $0.10 \% \mathrm{HCHO} 10 \mathrm{~m} l$ をいれたデシケー ター内で, $20^{\circ} \mathrm{C}, 96$ 時間の暴露実験を行った。 その結果, PE 包装したカゼイン, デンプンと もに吸着は見られるものの, いずれも $\mathrm{PE}$ 包装 品では $0.030 \mathrm{mg} / \mathrm{g}$ の HCHO が検出され。カゼ インは無包装 $(0.72 \mathrm{mg} / \mathrm{g})$ に対して $4.2 \%$ ，デ ンプンは無包装 $(0.58 \mathrm{mg} / \mathrm{g})$ に対して $5.2 \%$ の 透過吸着が認められたに過ぎなかった。

また PP 包装品は無包装カゼインの吸着量に 対して $2.8 \%(0.020 \mathrm{mg} / \mathrm{g})$, デンプンの吸着量 に対して $2.9 \%(0.015 \mathrm{mg} / \mathrm{g})$ とさらに低い值 であった。ここに示した PEと PP の透過性の 違いは既報17)のガスバリアー性と一致するもの であり，これらの結果はプラスチック包装材が 食品への HCHO の侵入を防ぐのに有効で あることを示している。な体本実験に用い た乾湎抢よびスパゲッティの袋は赤外分光 光度計で測定した結果, Fig.7に示すとお りいずれも外層, 内層ともに PPの複層フ ィルム（乾湎の袋：外層 $0.033 \mathrm{~mm}$, 内層 $0.025 \mathrm{~mm}$ ，スパゲッティの袋：外層 0.030 $\mathrm{mm}$, 内層0.020mm) であり, このスパゲ ッティの袋を用いて同様に透過性の確認を 行ったが，いずれも同じ測定条件で定量下 限 $(0.005 \mathrm{mg} / \mathrm{g})$ 以下であった。

以上の結果から保存性のある食品でも開 封後は再度，ヒートシーラーなどで密封す 


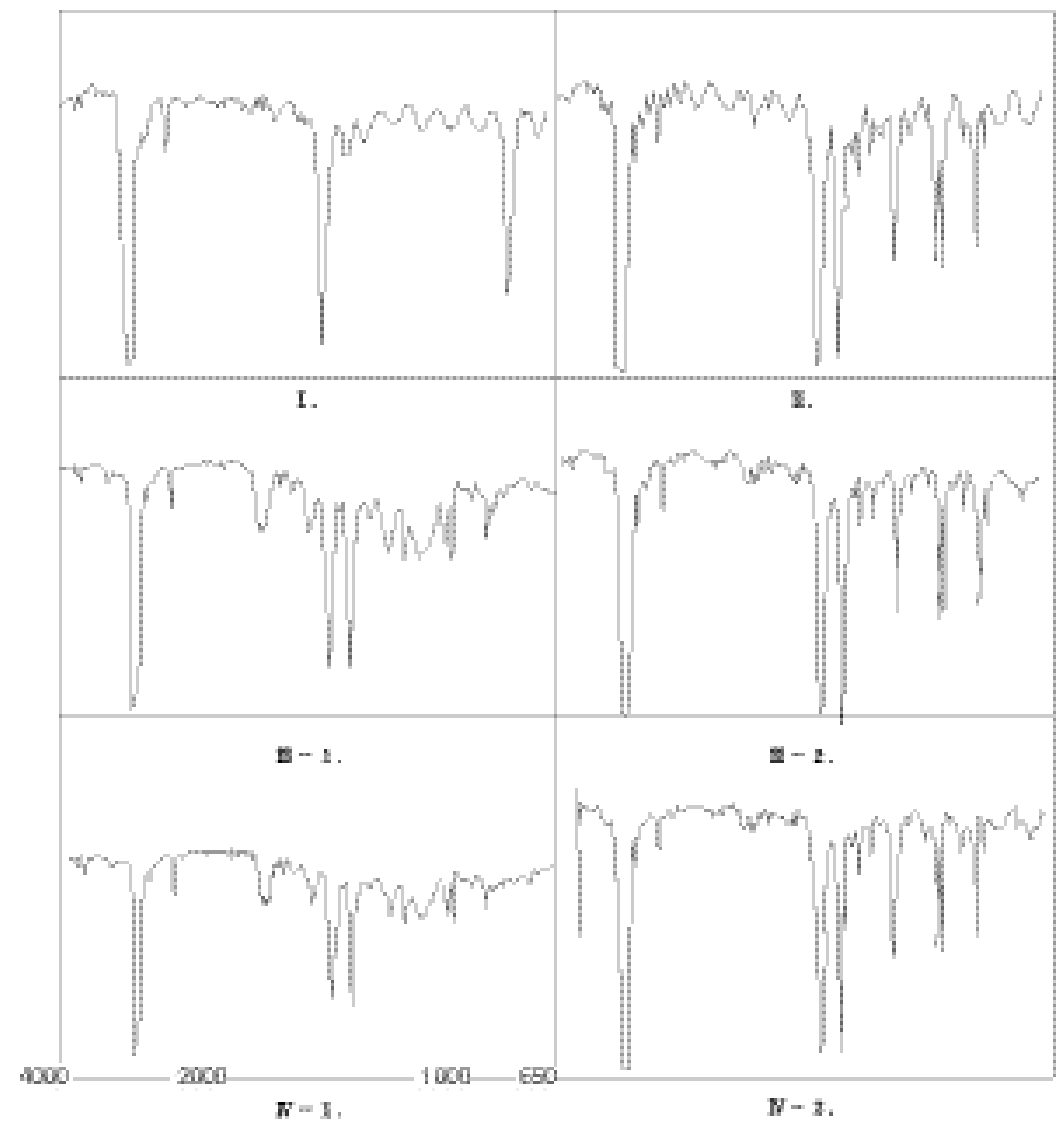

Fig.7 IR spectrum of films

I . Polyethylene film

III - 1 . Inner firm (hoshi-udon)

$\mathrm{N}-1$. Inner firm (spaghetti)
II. Polypropylene firm

III-2 . Outer firm (hoshi-udon)

$\mathrm{N}-2$. Outer firm (spaghetti)
るか, 気密性のあるフィルム袋に保存することで, 環境 中からの HCHO による污染を低減させることが可能で あることが示された。

\section{要旨}

ホルムアルデヒドの食品への移行と調理後の残存につ いて検討した。タンパク質や糖質を主成分とする食品は, 被曝濃度にかかわらず，HCHO の吸着が容易に起こり， 吸着活性は対照試料としてカゼイン，デンプン共に高く， 大豆油には吸着が見られなかった。またカゼイン，デン プンの HCHO 吸着は少なくとも96時間までは増加し， 保存が長期にわたるとさらに吸着量が増加する可能性が 示唆された。このことは一般に長期保存が可能なタンパ ク質や糖質に富む乾物や穀類などは HCHO の吸着濃度 が高まる可能性が高いことを示している。

また保存温度と HCHO 吸着量の関係では, 温度の上 昇に伴い気相中の HCHO 濃度も上昇し, 吸着量に関し ても正の相関を示すことが明らかとなった。さらに調理 による消長では茹でることにより 70〜 80\%が除去される が，粉ミルクのように，密封状態で加温溶解し全量摂取 するものでは，大部分が残存することが明らかとなった。 そこで食品への吸着を防ぐことを目的に $\mathrm{HCHO}$ のフィ
ルム透過性について検討した。その結果, フィルムの違 いによりガスバリアー性の違いが認められ，PPなどの 複層フィルムを使用し, 密封保存することが食品への $\mathrm{HCHO}$ の吸着防止に有効であった。

\section{謝 辞}

本研究を行うにあたり, 多大なる研究助成を賜りまし た浦上食品・食文化振興財団ならびに関係者各位に深謝 致します。

\section{文献}

1）アトピー環境研究会編：1999年度調査研究中間報告書シ ックハウス等症例集, アトピー環境研究会（1999）

2）シックハウス完全対策 : 建築知識, 43，3，124-196，工 クスナレッジ (2001)

3）後藤 稠, 池田直之, 原 一郎：産業中毒便覧, 10891096, 医歯薬出版 (1981)

4) Kamata,E., Nakadate, M., Uchida,O., Ogawa,Y., Kanako,T. and Kurokawa, Y.,: J. Environ. Path. Toxicol. Oncol, 15, 1-8 (1995)

5) Kamata, E., Nakadate, M., Uchida,O., Ogawa, Y., Suzuki, S., Kanako, T. Saito, M. and Kurokawa, Y. : J. Toxicol Sci. 22, 239-254 (1997)

6) N.Williams, R, T.:Detoxieation Mechanisms 2nd.edi., 334 
-335, 467 Chapman and Hell, London, (1959)

7）中島三郎：食品衛生研究，15，1，22-25（1965）

8）科学技術庁食品資源調查会編：五訂日本食品標準成分表

9）日本薬学会編：衛生試験法注解, 108-110, 金原出版 (1990)

10） E.Fedeli, M.Cirimele : J.Chromatogra., 15, 435, (1964)

11）城戸浩三，佐久間忠道 : 衛生化学， 25，1，39-43（1979）

12）小出圭子, 野田茂, 飛野敏明: 熊本県環境科学研究所 報， 26，38４0（1997）

13）日本薬学会編：衛生試験法注解，616～617, 金原出版
(1990)

14） John A. Troller, J.H..B.Christian(平田 学, 林 徹訳)： 食品と水分活性, 3-5, 学会出版センター（1993）

15）吉岡正則編：わかりやすい分析化学入門， 30～32, 廣川 書店 (1993)

16）依田隆一郎，大見俊彦，茂木幸夫，小西昭夫，山本清史， 藤井正美, 村上貴久: 食品衛生研究, 30，10，61-70（1980）

17）葛良忠彦, 平 和雄 : 新しい包装材料, 4-15, 共立出版 (1991) 